\title{
Actual use and satisfaction of lower extremity orthoses in neurological disorders
}

\section{Nörolojik hastalıklarda alt ekstremite ortezlerinin gerçek kullanımı ve memnuniyeti}

\author{
Sibel Başaran, ${ }^{1}$ İke Coşkun Benlidayı, ${ }^{1}$ Pembe Hare Yiğitoğlu, ${ }^{2}$ Neslihan Gökçen, ${ }^{1}$ Rengin Güzel ${ }^{1}$ \\ ${ }^{1}$ Department of Physical Medicine and Rehabilitation, Medical Faculty of Çukurova University, Adana, Turkey \\ ${ }^{2}$ Department of Physical Medicine and Rehabilitation, Near East University, Lefkosa, Cyprus
}

Received / Geliş tarihi: March 2015 Accepted / Kabul tarihi: July 2015

\begin{abstract}
Objectives: This study aims to investigate the use and degree of satisfaction of lower extremity orthoses in patients with neurological disorders.

Patients and methods: Between January and December 2007 and January and June 2013, a total of 193 patients (109 males, 84 females; mean age $26.5 \pm 22.8$ years; range 1 to 80 years) with 231 prescriptions were included. The prescriptions of lower extremity orthoses were extracted from the registers. Patients were interviewed via telephone call about six months after the prescription date and the acquirement, usage, compliance, and degree of satisfaction were questioned. The satisfaction was assessed using a five-point Likert scale (0-4).

Results: Of the 231 prescriptions, 198 (85.7\%) were reported being purchased. The main reasons for not purchasing were a lack of interest of the caregivers/patients, worsening/improving of the disease, belief of ineffectiveness, and cost/social security concerns. Among the devices which were purchased, $16.7 \%$ were reported to be never used, $22.7 \%$ were being used irregularly or quitted, and the rest $60.6 \%$ were being used on a regular basis. The main reason for not using the prescribed devices was related to the unsuitableness of the device over time. Overall satisfaction score was 2.48 $\pm 1.0(0-4)$ among the users. A statistically significant difference in the degree of satisfaction between the regular and irregular users was observed $(2.7 \pm 0.9$ vs. $1.8 \pm 1.1, \mathrm{p}=0.000)$.

Conclusion: The patients usually purchase the prescribed orthoses and the compliance is favorable. Overall satisfaction is moderate. To fulfill the gratification of the patients, physicians and caregivers should pay more attention to certain issues including the proper usage of the devices, regular follow-ups, patient education, and engagement of the users.
\end{abstract}

Keywords: Compliance; orthopedic shoes; orthosis; satisfaction.

$\ddot{O Z Z}$

Amaç: Bu çalışmada nörolojik hastalıkları olan hastalarda alt ekstremite ortezlerinin kullanımı ve memnuniyet derecesi araştırıldı.

Hastalar ve yöntemler: Ocak-Aralık 2007 ve Ocak-Haziran 2013 tarihleri arasında, 231 reçete yazılan toplam 193 hasta (109 erkek, 84 kadın; ort. yaş $26.5 \pm 22.8$ yıl; dağılım 1-80 yıl) çalışmaya alındı. Alt ekstremite ortezlerine ait reçetelere, kayıtlardan ulaşıldı. Reçete tarihinden yaklaşık altı ay sonra hastalarla telefon görüşmesi yapıldı ve tedarik, kullanım, kompliyansları ve memnuniyet dereceleri sorgulandı. Memnuniyetleri beş puanlık Likert ölçeği (0-4) ile değerlendirildi.

Bulgular: Hastalar tarafından 231 reçetenin 198'inin (\%85.7) yaptırıldığı bildirildi. Başlıca yaptırılmama nedenleri hastanın/bakıcının ilgisizliği, hastalığın kötüleşmesi/iyileşmesi, etkili olmayacağına inanma ve maliyet/sosyal güvence hususları idi. Yaptırılan cihazların \%16.7'sinin hiç kullanılmadığı, \%22.7'sinin düzensiz olarak kullanıldığı veya bırakıldığı ve geri kalan \%60.6'sının ise düzenli olarak kullanıldığı bildirildi. Reçete edilen cihazların başlıca kullanılmama nedeni, cihazın zaman içerisinde uygunsuz hale gelmesi ile ilgili idi. Kullanıcılar arasında genel memnuniyet skoru 2.48 \pm 1.0 (0-4) idi. Düzenli ve düzensiz kullanıcılar arasında memnuniyet derecesi açısından istatistiksel olarak anlamlı bir fark gözlendi $(2.7 \pm 0.9$ vs $1.8 \pm 1.1, \mathrm{p}=0.000)$.

Sonuç: Hastalar reçete edilen ortezleri genellikle yaptırırlar ve kompliyansları iyi düzeydedir. Genel memnuniyetleri ise, orta derecededir. Hastaların memnuniyetini artırmak için, hekimler ve bakıcılar cihazların uygun kullanımı, düzenli takip, hasta eğitimi ve kullanıcıların müdahil edilmesi gibi konulara daha fazla önem vermesi gerekmektedir.

Anahtar sözcükler: Kompliyans, ortopedik ayakkab1, ortez, memnuniyet.

Corresponding author / İletişim adresi: Sibel Başaran, MD. Çukurova Üniversitesi Tıp Fakültesi Fiziksel Tıp ve Rehabilitasyon Anabilim Dalı 01330 Balcalı, Adana, Turkey. e-mail / e-posta: sbasaran@cu.edu.tr 
The lower extremity orthoses are prescribed for a variety of disorders in rehabilitation and rheumatology clinics. ${ }^{[1]}$ The main indications for the lower extremity orthoses are neuromuscular dysfunction, osteoarthritis of the knee or ankle, and foot disorders. ${ }^{[1,2]}$ Orthoses [including the ankle foot orthoses (AFOs), knee ankle foot orthoses (KAFOs), orthopedic shoes (OS), braces, and insoles] are used for aforementioned indications to improve walking ability, prevent contractures, correct, or minimize the progression of deformities. ${ }^{[3]}$ Nevertheless, without a fully acceptance of the orthoses by patients, it would be challenging to achieve favorable outcomes. Fitting problems, overweight of the device, difficulty in donning and doffing, and lack of interest of the caregivers may hinder or obstruct the satisfaction, compliance and, acceptance, eventually.

In the literature, the satisfaction, use and compliance rates regarding the lower extremity orthoses have been addressed in a limited way. ${ }^{[4,5]}$ The primary aim of this study was to investigate the usage rate of lower extremity orthoses among the patients attending a physical medicine and rehabilitation clinic. The secondary objectives were to determine the degree of satisfaction and compliance among the users and to elucidate the reasons for refusal in patients not wearing their prescribed devices.

\section{PATIENTS AND METHODS}

Neurologically disabled patients who were prescribed lower extremity orthoses and OS between two separate time periods (January and December 2007 and January and June 2013) were investigated. Data regarding the diagnoses and prescribed devices were extracted from the registers. A total of 617 prescriptions for 464 patients were identified. Due to the missing data in the registries and contact problems, a total of 193 patients (109 males, 84 females; mean age $26.5 \pm 22.8$ years; range 1 to 80 years) with $231 \mathrm{AFO}, \mathrm{KAFO}$, and OS prescriptions were included in this study. The contact information of the patients was obtained from the registers. The patients without any contact information in records and those who were unable to be reached via phone call were excluded. The flowchart of the study is illustrated in Figure 1.

The demographic variables including age, sex, and education status as well as the information on the diagnosis and type of the prescribed device were noted. All patients were interviewed via telephone call about six months after the prescription date. The patients were interviewed according to a self-designed multiitem questionnaire. During the telephone interview, the patients were initially asked whether they purchased the prescribed device or not. The patients who did not purchase the device were interviewed regarding the main reason for it: (i) lack of interest of the caregivers/ patients, (ii) belief of ineffectiveness, (iii) cost and social security concerns, (iv) cosmetic reasons, and (v) exitus of the patient. Those who purchased their devices were interviewed further regarding the usage (never used, quitted using/irregular usage, and regular use). Non-users/irregular users were asked for stating one of the following reasons for not using the device: (i) not fitting properly, (ii) difficulty in donning/ doffing, (iii) not appreciating the possible benefits, (iv) overweight of the device, (v) unsuitableness of the device over time (child's growing up, patients' recovery, wearing off the device), (vi) worsening/ improving of the disease and/or exitus of the patient, (vii) cosmetic reasons, and (viii) other reasons. Among the regular users, on the other hand, the degree of satisfaction was assessed using a five-point Likert scale (0: very dissatisfied, 1: dissatisfied, 2: somewhat satisfied, 3: satisfied, and 4: very satisfied).

\section{Statistical analysis}

Statistical analysis was performed by PASW version 17.0 software (SPSS Inc., Chicago, IL, USA). The normality of the variables was analyzed. The MannWhitney $U$ and Kruskal-Wallis tests were used to analyze abnormally distributed variables between the user groups. The data were expressed in mean \pm standard deviation. A $p$ value of $<0.05$ was considered statistically significant.

\section{RESULTS}

The demographic characteristics of the study group are shown in Table 1. Among the adult patients

Table 1. The demographic characteristics of the patients

\begin{tabular}{lccc}
\hline Variable & $\mathrm{n}$ & $\%$ & Mean $\pm \mathrm{SD}$ \\
\hline Age (years) & & & $26.5 \pm 22.8$ \\
Sex & & & \\
$\quad$ Male & 109 & & \\
$\quad$ Female & 84 & & $7.1 \pm 4.3$ \\
Education status (year) & & & \\
Diagnosis & & & \\
$\quad$ Cerebral palsy & 64 & 33.2 & \\
$\quad$ Post-stroke hemiplegia & 43 & 22.3 & \\
$\quad$ Polyneuropathy & 31 & 16.1 & \\
$\quad$ Spinal cord injury & 16 & 8.3 & \\
$\quad$ Neuromuscular diseases & 11 & 5.7 & \\
$\quad$ Traumatic brain injury & 3 & 1.6 & \\
$\quad$ Other disorders & 25 & 13 & \\
SD: Standard deviation; ${ }^{*}$ Full-time educated years in adult patients ( $\geq 18$ years).
\end{tabular}




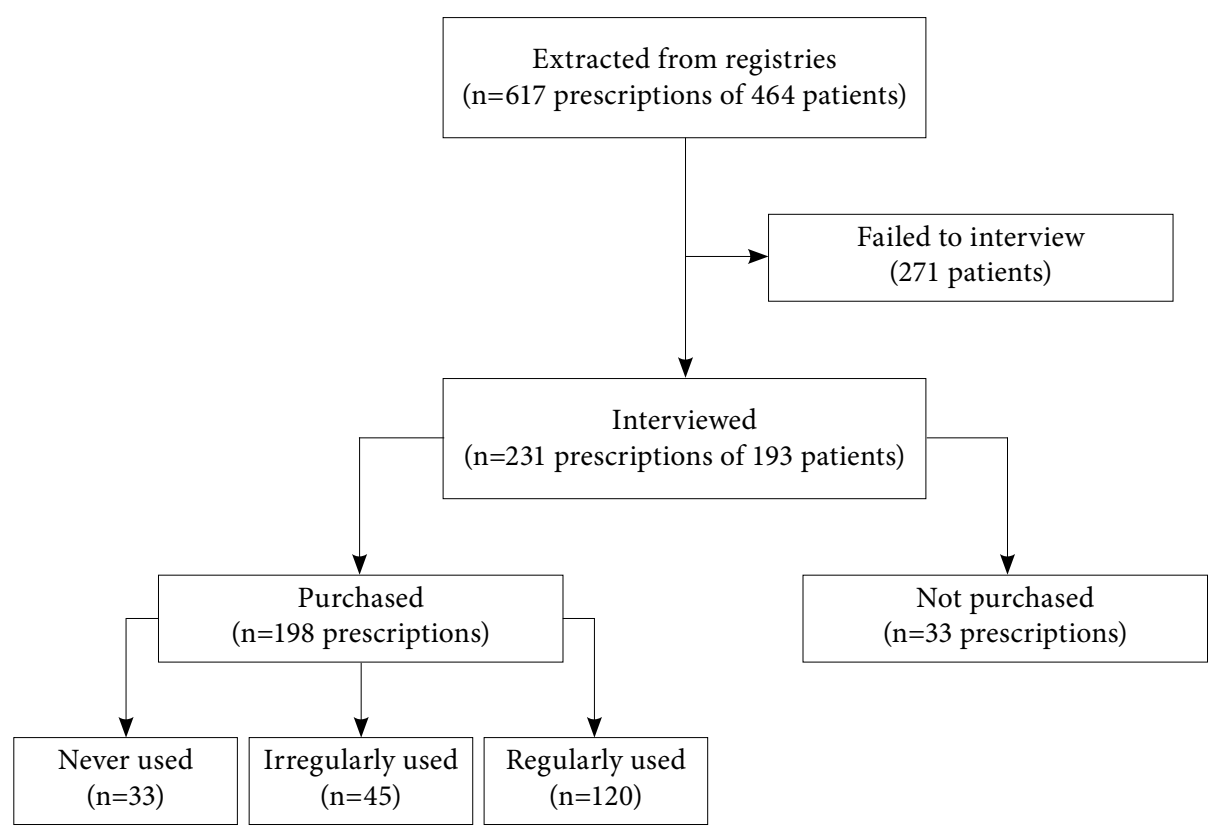

Figure 1. Flowchart of the study.

( $\geq 18$ years old), the mean full-time education duration was $7.1 \pm 4.3$ years. For orthotic prescriptions, the diagnosis were listed in Table 1 . Among the prescribed orthoses, $54.5 \%, 18.2 \%$, and $27.3 \%$ were AFO, KAFO, and $O S$, respectively.

Among 231 prescriptions, 198 (85.7\%) were reported to be purchased. The main reasons for not purchasing the orthoses are listed in Table 2. Of the devices which were purchased, $16.7 \%$ were reported to be never used, $22.7 \%$ were being used irregularly or quitted, and the rest $60.6 \%(n=120)$ were being used on a regular basis. The most common diagnoses of the patients who never used their orthoses were polyneuropathy, post-stroke hemiplegia syndrome, cerebral palsy, spinal cord injury, other disorders and neuromuscular diseases. The reasons for not using or irregular use of the prescribed devices are also shown in Table 3.

The overall satisfaction score among the users was $2.48 \pm 1.0(0-4)$. Based on the prescribed orthoses (AFO, KAFO, and OS), the satisfaction scores of the

Table 2. The main reasons for not purchasing the orthoses

\begin{tabular}{lcc}
\hline Reason & $\mathrm{n}$ & $\%$ \\
\hline Lack of interest of caregivers/patients & 21 & 63.6 \\
Worsening/improving of the disease & & \\
$\quad$ and/or exitus of the patient & 5 & 15.2 \\
Belief of ineffectiveness & 4 & 12.1 \\
Cost and social security concerns & 3 & 9.1 \\
\hline
\end{tabular}

patients were $2.3 \pm 1.1,2.8 \pm 0.8$ and $2.6 \pm 0.9$, respectively, indicating no statistically significant difference among the users $(\mathrm{p}=0.12)$.

We also analyzed the overall satisfaction of the patients according to the regular and irregular usage of the orthoses and found no statistically significant difference in the degree of satisfaction $(2.7 \pm 0.9$ vs. $1.8 \pm 1.1, \mathrm{p}=0.000$ ). Besides, the satisfaction was analyzed separately for each orthosis group and a significant difference was found among the regular and irregular users of AFO and OS ( $p=0.000$ vs. $p=0.03$ ). However, the degree of satisfaction did not differ between the regular and irregular KAFO users $(\mathrm{p}=0.75)$.

\section{DISCUSSION}

The use of lower extremity orthoses has become part of the rehabilitation strategy of neurologically

Table 3. The main reasons for not using/irregular use of the prescribed orthoses

\begin{tabular}{lcc}
\hline Reason & $\mathrm{n}$ & $\%$ \\
\hline Unsuitableness of the device over time & 36 & 46.2 \\
Not fitting properly & 17 & 21.8 \\
Not appreciating the possible benefits & 9 & 11.5 \\
Difficulty in donning/doffing & 6 & 7.7 \\
Worsening/improving of the disease & & \\
$\quad$ and/or exitus of the patient & 5 & 6.4 \\
Overweight of the device & 3 & 3.8 \\
Cosmetic reasons & 1 & 1.3 \\
Other reasons & 1 & 1.3 \\
\hline
\end{tabular}


disabled patients. ${ }^{[1]}$ Walking aids, custom-made OS, AFOs, and KAFOs are the main assistive devices prescribed to a wide variety of conditions. ${ }^{[1]}$ The orthoses are commonly recommended to improve outcome, overcome mechanical disabilities, and provide independent mobility. To be fully effective, the orthoses must be used by for whom they are prescribed.

Once the orthoses are manufactured, the patients usually attend for the propriety of the devices. Then, they do not attend to the scheduled visits regularly. Therefore, the compliance and satisfaction of the patients may not be able to be determined. Furthermore, data on the compliance or satisfaction of the orthoses have been rarely reported in the current literature. Few studies reported the use of a variety of assistive technology. Dijcks et al. ${ }^{[6]}$ investigated the non-use of assistive technology in the Netherlands. They analyzed the assistive devices according to 14 categories including orthoses/OS. Among 210 orthoses/OS users, all were reported to ever use, while $91 \%$ used the devices on a regular basis. In our study, $83.3 \%$ of the patients were reported to ever use and $60.6 \%$ were reported to use the devices regularly. We found that the main reasons for not using the prescribed devices were mainly device-related concerns and patients' recovery. Dijcks et $a .^{[6]}$ also reported their results according to the actual use, compared to expected use, as "more than expected," "as much as expected," and "less than expected." They found that many reasons for nonuse were for the devices among "less than expected users." Concerning the orthoses/OS, similar to our results, the frequent reasons for less than expected use were "disabilities decreased/the problem solved" and "not fit well/caused pain or irritability." The authors speculated that, for some reasons, the actual prevalence of non-use is higher than which was reported in their study. They also advised to further investigate the determinants of non-use more specifically for the certain types of devices. In our study, among the assistive devices, we excluded prostheses, walking aids, insoles and upper extremity orthoses. Only AFOs, KAFOs, and OS were selected from our registries and questioned for the reasons for non-use more specifically and comprehensively.

Regarding the OS, few studies investigated the use and usability in the literature. Varying rates of non-use have been reported to be 20 to $25 \%$ for the first-time users and $4-19 \%$ for experienced users. ${ }^{[7]}$ In a study investigating the use and usability of OS for several pathologies, Van Netten et al. ${ }^{[7]}$ found that $81 \%$ of the patients used their OS frequently, $13 \%$ occasionally, and $6 \%$ did not use their OS three months after delivery. They reported that effectiveness (e.g., change in pain), efficiency (e.g., donning/doffing, fit, ease of walking with OS), and satisfaction (e.g., the patient's opinion of the cosmetics of OS) were significantly better in the frequent user group. In our study, the regular use of OS was $70.4 \%$ and the degree of satisfaction was significantly higher among the regular users. In another study by van Netten et al., ${ }^{[8]}$ patients' expectations and actual usage of OS were investigated. They demonstrated that the expectations of the patients who frequently used their OS were in consistent with their experiences. However, the expectations of the patients who did not use their OS were much higher than their experiences.

In another study, Vinci and Gargiulo ${ }^{[9]}$ investigated the compliance with AFO in Charcot-Marie-Tooth disease (CMT). In this study, 25 patients with CMT disease were prescribed AFO for dropped foot. The authors reported that 12 patients (48\%) did not purchase the devices and only five patients (20\%) used AFOs. They concluded that the compliance with AFOs was poor and the reasons to discard AFOs were that the AFOs highlighted their disability, were not essential for their limited daily walking and were uncomfortable. On the other hand, in our study group, $14.7 \%$ of prescribed devices were not purchased and the main reasons were a lack of interest of the caregivers/patients, worsening/ improving of the disease, belief of ineffectiveness, and cost/social security concerns.

Furthermore, in another study investigating the assistive technology abandonment, 227 adults with various disabilities responded to a survey on device selection, acquisition, performance, and use. ${ }^{[10]}$ The results of the study showed that $29.3 \%$ of all devices were abandoned and mobility aids were more frequently abandoned devices. The authors reported four major factors which were significantly related to abandonment: lack of consideration of user opinion in selection, easy device procurement, poor device performance, and change in user needs or priorities. The authors, therefore, suggested emphasizing consumer engagement and long-term needs of consumers to reduce device abandonment and enhance the satisfaction of the users.

Nonetheless, there are some limitations to our study. Relatively small number of questioned orthoses and not including specific types of orthoses or diseases 
to compare the results to different studies can be regarded as the study limitations.

In conclusion, patients usually purchase the prescribed orthoses and the compliance is favorable. Lack of interest of the caregivers/patients was the main reason for not purchasing. In addition, the primary cause for not using the prescribed devices was unsuitableness of the device over time. Since the overall satisfaction was moderate, physicians and caregivers should pay more attention to certain issues including the proper usage of the devices, regular follow-ups, patient education, and engagement of the users to fulfill the gratification of the patients.

\section{Declaration of conflicting interests}

The authors declared no conflicts of interest with respect to the authorship and/or publication of this article.

\section{Funding}

The authors received no financial support for the research and/or authorship of this article.

\section{REFERENCES}

1. Hennessey WJ. Lower limb orthotic devices. In: Braddom RL, editor. Physical Medicine and Rehabilitation. 4th ed. Philadelphia: Elsevier Saunders; 2011. p. 333-57.
2. Malkin K, Dawson J, Harris R, Parfett G, Horwood P, Morris C, et al. A year of foot and ankle orthotic provision for adults: prospective consultations data, with patient satisfaction survey. Foot (Edinb) 2008;18:75-83.

3. Doğan A, Mengüllüoğlu M, Özgirgin N. Evaluation of the effect of ankle-foot orthosis use on balance and mobility in hemiparetic stroke patients. Disabil Rehabil 2011;33:1433-9.

4. Murray CD, Fox J. Body image and prosthesis satisfaction in the lower limb amputee. Disabil Rehabil 2002;24:925-31.

5. Garralda ME, Muntoni F, Cunniff A, Caneja AD. Kneeankle-foot orthosis in children with duchenne muscular dystrophy: user views and adjustment. Eur J Paediatr Neurol 2006;10:186-91.

6. Dijcks BP, De Witte LP, Gelderblom GJ, Wessels RD, Soede M. Non-use of assistive technology in The Netherlands: a non-issue? Disabil Rehabil Assist Technol 2006;1:97-102.

7. van Netten JJ, Jannink MJ, Hijmans JM, Geertzen JH, Postema K. Use and usability of custom-made orthopedic shoes. J Rehabil Res Dev 2010;47:73-81.

8. van Netten JJ, Jannink MJ, Hijmans JM, Geertzen JH, Postema K. Patients' expectations and actual use of custommade orthopaedic shoes. Clin Rehabil 2010;24:919-27.

9. Vinci P, Gargiulo P. Poor compliance with ankle-footorthoses in Charcot-Marie-Tooth disease. Eur J Phys Rehabil Med 2008;44:27-31.

10. Phillips B, Zhao H. Predictors of assistive technology abandonment. Assist Technol 1993;5:36-45. 